\title{
Serological, hematological, Biochemical and Oxidative Markers During Foot and Mouth Disease Serotype ' 0 ' Infection, Egypt
}

\author{
Nasr A.M.NASR EL-DEEN ${ }^{1}$, Ahmed N F NEAMAT-ALLAH ${ }^{1 *}$, Lila Georgy RIZK ${ }^{2}$ and Rania Samy Gergis FAREED ${ }^{3}$ \\ ${ }^{1}$ Department of Clinical Pathology, Faculty of Veterinary Medicine, Zagazig University, 1 Alzeraa Street \\ Postal Code 44511, Zagazig City, Sharkia Province, Egypt. \\ ${ }^{2}$ Chief Researcher, Buffalo's disease Department. Animal Health Research Institute, El-Doki, Egypt \\ ${ }^{3}$ Animal Health Institute, Sharkia Province, Egypt. \\ *corresponding author: drnemovete @yahoo.com
}

Bulletin UASVM Veterinary Medicine 74(2)/2017

Print ISSN 1843-5270; Electronic ISSN 1843-5378

doi:10.15835/buasvmen-vm:0055

\begin{abstract}
Foot and mouth disease (FMD) is an extremely grave communicable disease of livestock. It affects all wild and domestic animals with cloven hoof. It is caused by Aphtho virus (Apthous fever) or (FMDV) foot and mouth disease virus which is originated from family Picornaviridae. 30 adult female water buffaloes, 3-5 years old infected with FMD serotypes, 0 . These animals were located at Sharkia governorate, Egypt during the period beetwen December 2014 to March 2015. Hematological findings showed no significant change in erythrogram and reduction in total leukocytes in the early stage of FMDV infection. Moreover development of macrocytic normochromic anemia and increase in total leukocytes and lymphocytic counts was reported in the late stage of infection. A significant decrease in cholesterol, progesterone, total proteins, albumin , globulins, calcium and sodium levels in infected groups, while a significant increase in serum activities of ALT ,AST, glucose, total, direct, indirect bilirubine, phosphorous potassium, NO. MDA, CK-MB, LDH and CTNI. Without alterations in creatinine level.
\end{abstract}

Keywords: buffaloes, hematology, biochemical, oxidative, cardiac.

\section{INTRODUCTION}

Foot and mouth disease (FMD) is an extremely serious communicable livestock diseases that affect all wild and domestic animals with cloven hoof (Blancou, 2002). It is caused by Aphtho virus (Apthous fever) or foot and mouth disease virus (FMDV) from family Picornaviridae (Radostits et al., 2007). FMDV subsist as seven serotypes which diverse immunologically, namely A, C, O, Asia ${ }_{1} \mathrm{SAT}_{1}$, $\mathrm{SAT}_{2}$ and $\mathrm{SAT}_{3}$ in which extra antigenic subtypes are present (Reid et al., 2003)

Affected animals usually showed high fever, stop eating, salivation and less milk yield (Baluka, 2016). The disease is identified by blister like injuries on the mouth, lips, nose, teats, tongue, and between the toes (Mahmoud and Neamat-Allah,
2016). FMD can cause severe problems for animals with cloven hooves with the potential of causing severe economic losses and trade distributions in animals and animal products (Lubroth, 2002). The disease spreads directly through the contact with infected animal, mechanical transfer of people, contact by animal products, vehicles, wild animals and birds, fomites and air borne way (Sellers and Gloster, 2008).

Although FMD is firstly diagnosed clinically and confirmed by isolation and identification of virus, the serological valuation of antibodies is substantial (Hamblin et al., 1987). The enzyme linked immunosorbent assay (ELISA) has now largely replaced serum neutralization test (SNT) 
for routine testing of animal sera for antibodies (Armstrong and Barnett, 1989)

Antibodies to capsid proteins (structural proteins) are manufacture from animals either infected or vaccinated but antibodies to nonstructural proteins (NSP) are only manufacture from infected one (Rodriguez and Gay, 2011). So, 3ABc-ELISA (The most reliable indicator for NSP) is highly suitable for large scale testing and can therefore be adapted for monitoring and eradication programs as it allows differentiation between infected and vaccinated animals (Longjam et al., 2011) .

FMD has a public health significance as the virus has been isolated from human cases so no doubt that FMDV is zoonotic (Berrios, 2007). The work was planned to investigate effects of FMD on water buffaloes through hematological, biochemical, ovarian activity and oxidative status.

\section{MATERIAL AND METHODS}

\section{Animals:}

This study was conducted on 50 adult female water buffaloes, 3-5 years old, (30 suffering from all signs suggesting FMD infection and 20 healthy animals from free FMD region). These animals were located at Sharkia governorate, Egypt during the period beetwen December 2014 to March 2015.

Blood sampling: Each animal through puncture of jugular vein, two blood samples was harvested. The first sample was collected in EDTA vacutainer tubes for hematological studies according to standard techniques described by (Douglas \& Wardrop, 2010) .The second portion was collected in centrifuge tubes for separation of serum for biochemical studies and serological assay of FMDV NSP and serotyping. Blood collected at 1-2 days and one week from appearance of clinical signs.

Serological assay: Portion of obtained serum were used for detection of FMDV NSP using kits of Prio CHECK FMDV NS according to (Sorensen et al., 1998) . FMDV Serotyoing using the according to Grazioli et al., (2012) using solid phase competitive ELISA kits.

Hematological studies: Complete blood count done using automatic cell counter (Sysmex KX-21N).

Biochemical studies: Other portion of serum were used to determine total proteins (TP), albumin and globulins levels, alkaline phosphatase (ALP), alanine aminotransferase (ALT) and aspartate aminotransferase (AST) activities, total and direct bilirubin levels, urea, creatinine, cholesterol, glucose, calcium, inorganic phosphorus, sodium , potassium, nitric oxide and malondialdehyde levels by using Vitro Biodiagnostic, Egypt.

Statistical analysis: All values were presented as means ( \pm ) standard error (SE). The significant difference between the means of the groups was statistically analyzed by independent $F$ test. The significance was set as $\mathrm{P} \leq 0.05$ (Tamhane and Dunlop, 2000).

\section{RESULTS AND DISCUSSION}

Foot and mouth disease (FMD) is an economically viral disease highly infectious to all cloven hoof farm animals including buffaloes, cattle, swine, sheep and goats. The disease is caused by RNA virus belongs to the genus apthovirus within the family Picorna viridae. FMDV is divided into seven serotypes (A, C, 0, SAT1, SAT2 SAT3 and Asia 1,) (Grazioli et al., 2013; Valdazo-González et al., 2012). FMD infected animal's revealed fever, vesicles in mouth and on muzzle, teats and feet (Clavijo et al., 2004).

The present study was carried out on female water buffaloes tribulation some clinical marks suggested to be FMDV infection. The clinical examination in early stage (Figs.1-4) revealed fever, depression, anorexia, lameness, foamy and ropy salivation, and vesicular eruption on mucosa of bucal cavity and interdigital space causing

Tab.1. Detection of FMDV NSP in early and late stage of FMD

\begin{tabular}{ccccc}
\hline Sample No. & Time of sampling & OD sample & $\begin{array}{c}\text { PI } \\
\%\end{array}$ & Result \\
\hline 1 & $1^{\text {st }}$ day & $1.35 \pm 0.08$ & $27.00 \pm 4.38$ & - ve \\
\hline 2 & After 1 week & $0.39 \pm 0.03$ & $78.33 \pm 1.95$ & + ve \\
\hline
\end{tabular}




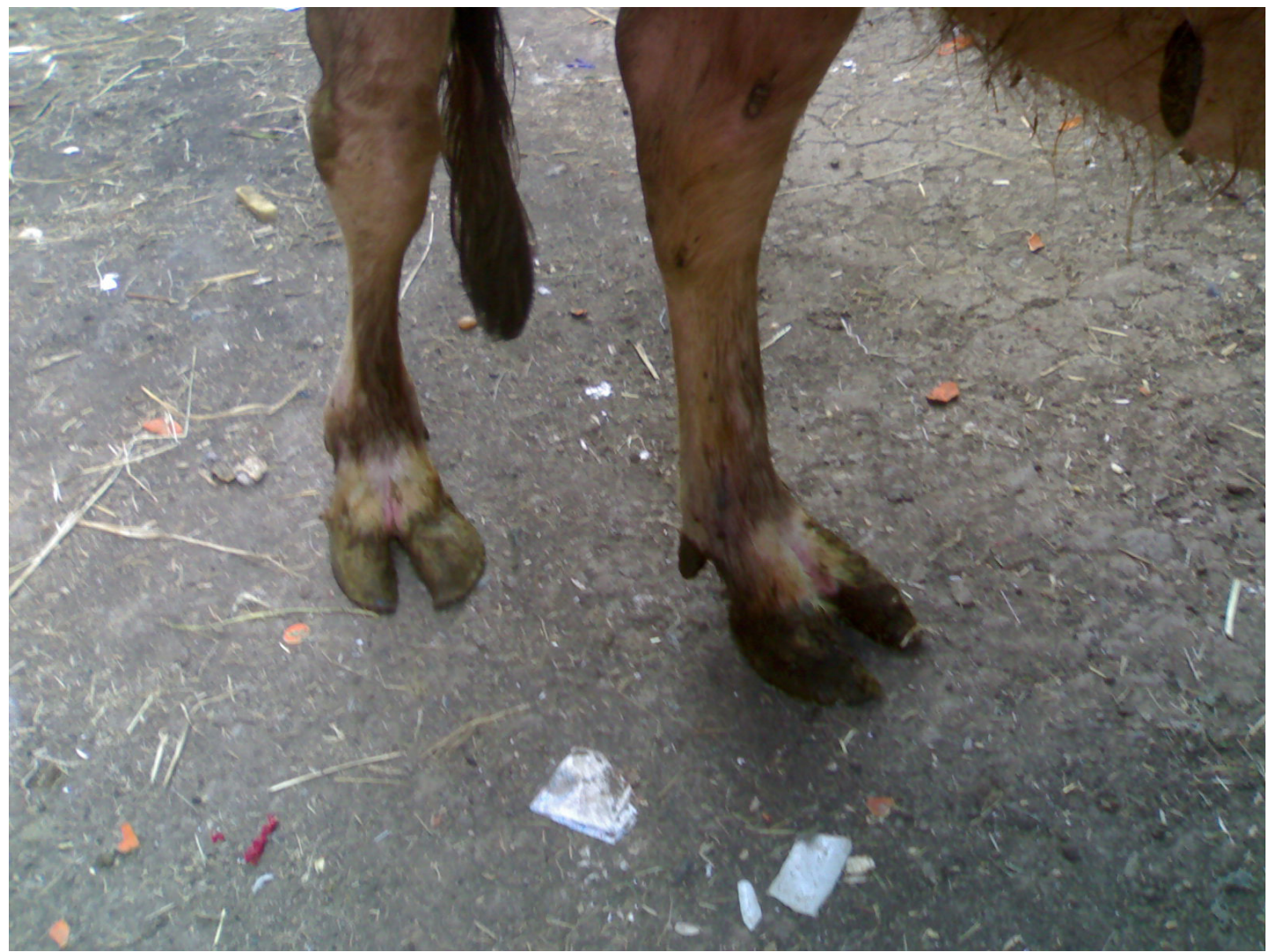

Fig.1. Buffalo infected with FMDV showing ulceration between claws.

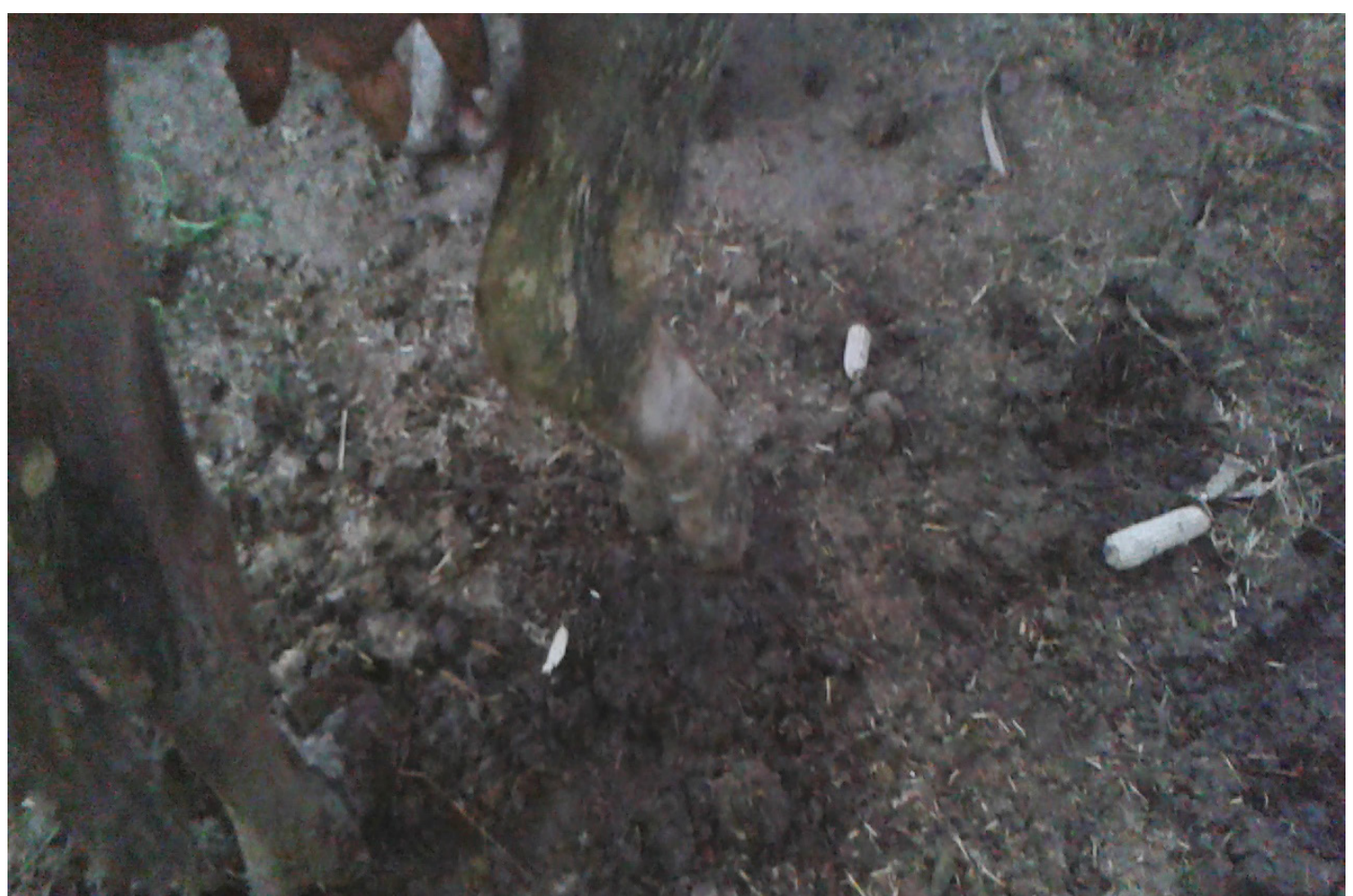

Fig. 2. Buffalo infected with FMDV showing showing lamness. 


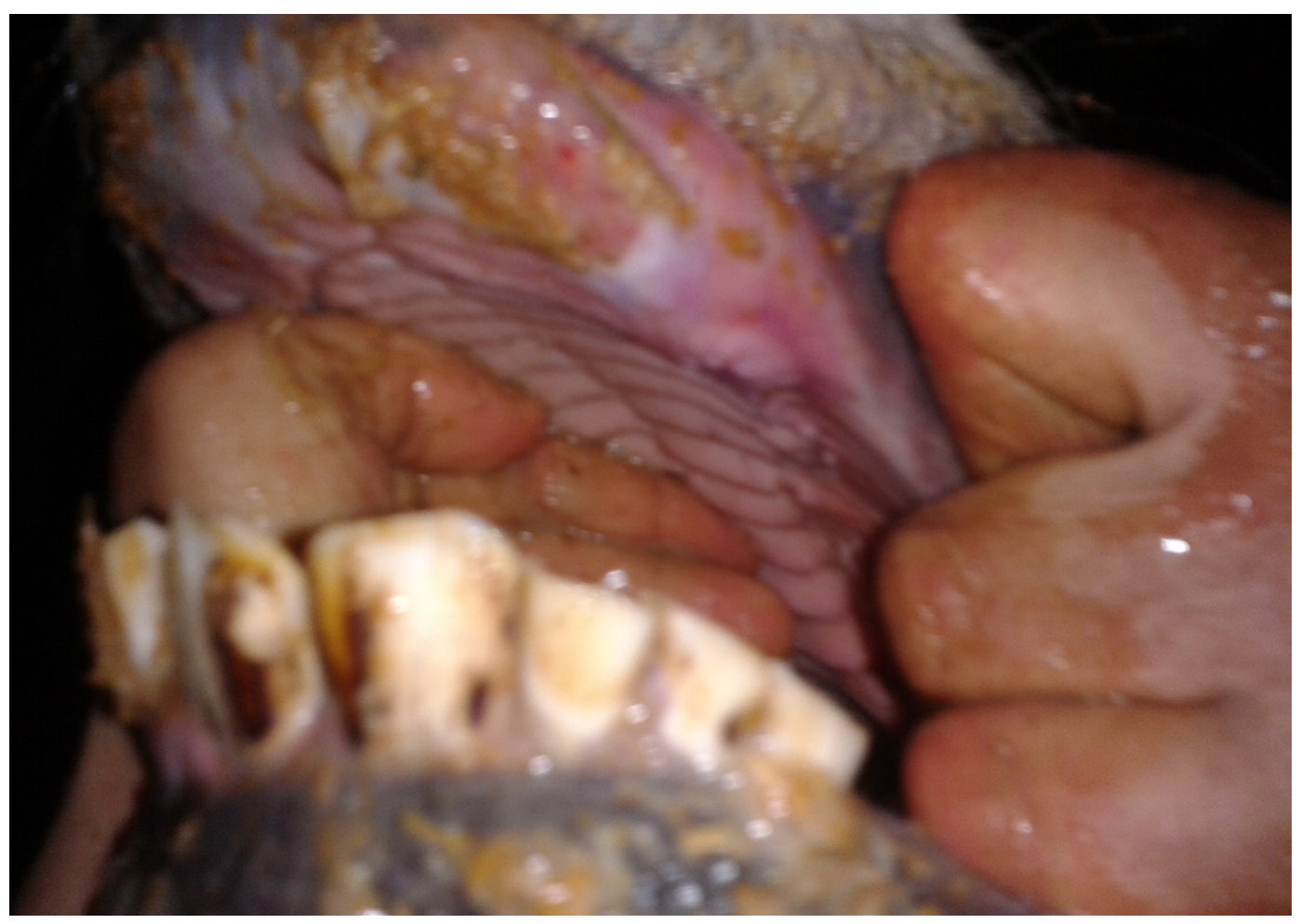

Fig.3. Buffalo infected with FMDV showing ulceration on hard palate.

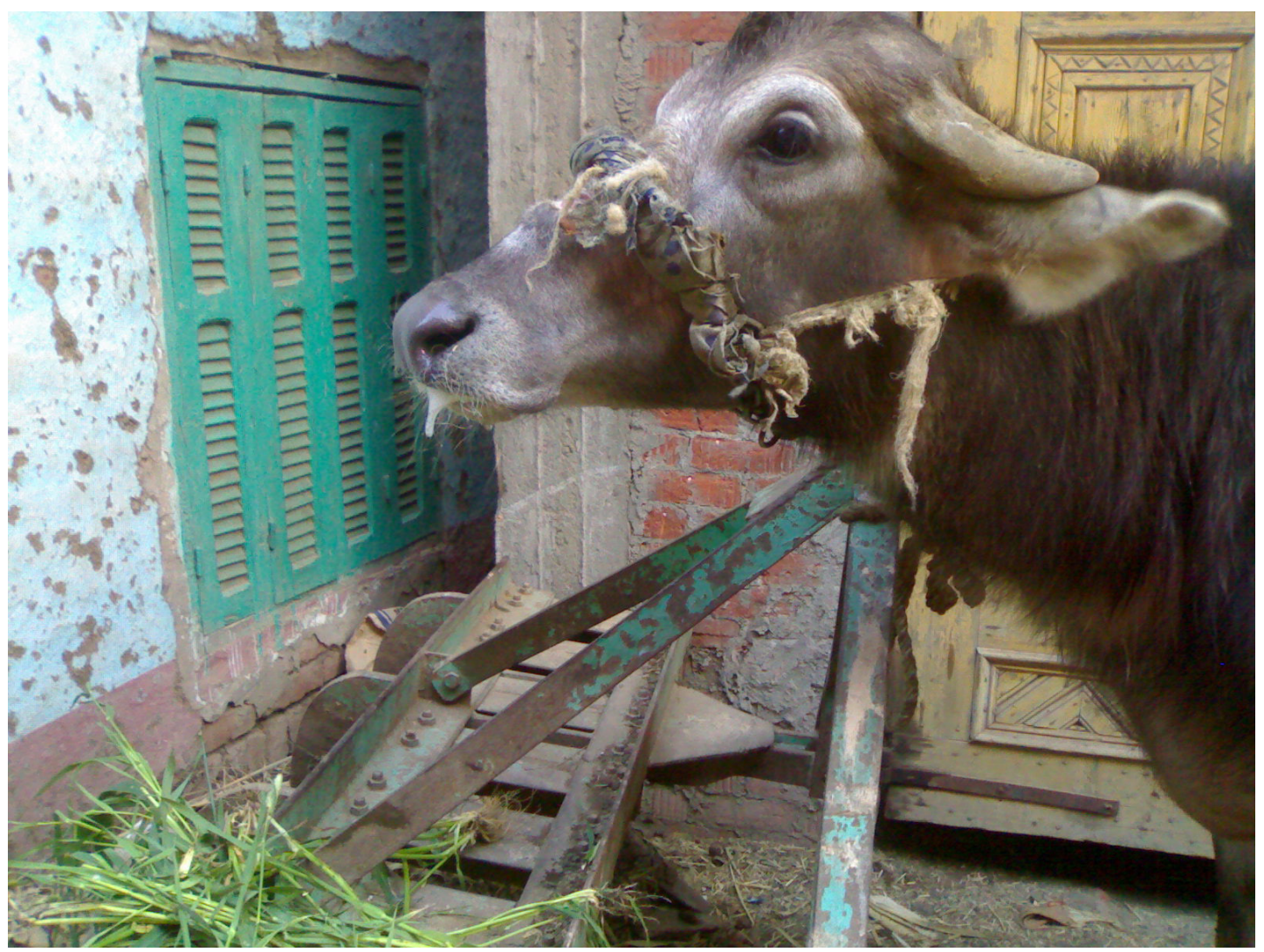

Fig.4. Buffalo infected with FMDV showing salivation. 
sever lamness (Mahmoud and Neamat-Allah, 2016). Animals in late stage showed the same clinical signs except fever as reported (Radostits et al., 2007).

Regarding to the serological assessment, animals in the early stage revealed negative antibodies against FMDV NSP (non structural protein). While in the late stage of infection positive antibodies against FMDV NSP were detected. Our results supported the previously obtained by ElShehawy et al. (2004) and Ali et al. (2011).

The antibodies against non structural protein of FMD virus could not be detected during first few days after experimental and natural infection as the immune response to NSP appear later than the response to structural protein of the virus. Moreover, FMD virus is excreted 24-48 hours before the onset of the clinical signs and viremia persists for some days then the serum antibodies developed after decreasing of viremia and persist for 40 weeks post infection (Declercq, 2002).

Concerning to FMDV serotyping, our study revealed that the causative strain was " 0 ". The disease was diagnosed by Animal Health Research Institute Laboratory, El-Dokki, Cairo, Egypt. The same serotype was recorded in Egypt in 2002 (Aidaros, 2002).

Regarding the hematological results, gp (2) revealed no significant changes in erythrogram. Similar results were previously obtained by Nasr El-Deen (2013). While there was a significant decrease in RBCs count, hemoglobin concentration and PCV with the development of macrocytic normochromic anemia in the late stage of the disease (gp. 3). This may due to dietary intake of folic acid and vitamin B12 is inadequate, disturbed metabolism of liver and decreased absorption by damaged intestine. Nearly similar results were obtained by Ghanem and Abdel Hamid (2010) and El-Ashmawy et al. (2014) as they recorded a significant decrease in RBCs count, hemoglobin concentration and PCV secondary to FMD virus infection.

The leucopenia, observed in early stage of FMDV infection (gp.2) was due to lymphopenia. Such decrease in the lymphocytic count may be due to infection of $\mathrm{T}$ and $\mathrm{B}$ cells with FMDV for short time after infection, corresponding to the peak of viremia and thus causes a transient immunosuppression (Diaz and Sevilla, 2006). This transient immunosuppression facilitates systemic dispersal and shedding of virus into the environment (Parida et al., 2006). Moreover, Olabode et al., (2013) recorded a significant decrease in total leukocytes count in blood samples collected within 3 days post foot and mouth disease infection.

While there were a significant leukocytosis and lymphocytosis in the late stage of foot and mouth disease infection (gp.3) compared with the normal control group. Our results supported the previously obtained by Krupakaran et al.

Tab. 2. Effect of FMD on the erythrogram of buffaloes (mean values \pm SE)

\begin{tabular}{lccc}
\hline \multirow{2}{*}{ Parameters } & \multicolumn{3}{c}{ Groups } \\
\cline { 2 - 4 } & Control & Early stage of FMD infection & Late stage of FMD infection \\
\hline RBCs $10^{6} / \mu \mathrm{l}$ & $8.02^{\mathrm{a}} \pm 0.23$ & $7.20^{\mathrm{a}} \pm 0.52$ & $5.30^{\mathrm{b}} \pm 0.11$ \\
\hline $\mathrm{Hb}$ g\% & $11.00^{\mathrm{a}} \pm 0.31$ & $10.50^{\mathrm{ab} \pm 0.35}$ & $9.70^{\mathrm{b}} \pm 0.12$ \\
\hline $\mathrm{PCV} \%$ & $32.40^{\mathrm{a}} \pm 0.45$ & $31.00^{\mathrm{ab} \pm 0.42}$ & $30.20^{\mathrm{b}} \pm 0.33$ \\
\hline $\mathrm{MCV} \mathrm{fl}$ & $40.40^{\mathrm{b}} \pm 2.09$ & $43.06^{\mathrm{b}} \pm 2.40$ & $56.98^{\mathrm{a}} \pm 1.01$ \\
\hline $\mathrm{MCH} \mathrm{pg}$ & $13.71^{\mathrm{b}} \pm 0.35$ & $14.58^{\mathrm{b}} \pm 0.42$ & $18.30^{\mathrm{a}} \pm 0.56$ \\
\hline MCHC\% & $33.45^{\mathrm{a}} \pm 1.11$ & $33.87^{\mathrm{a}} \pm 0.62$ & $32.11^{\mathrm{a}} \pm 1.06$ \\
\hline WBCs $(103 / \mu \mathrm{l})$ & $8.13^{\mathrm{b}} \pm 0.45$ & $6.83^{\mathrm{c}} \pm 0.41$ & $9.60^{\mathrm{a}} \pm 0.27$ \\
\hline Lymphocytes $(103 / \mu \mathrm{l})$ & $4.20^{\mathrm{b}} \pm 0.20$ & $3.00^{\mathrm{c}} \pm 0.34$ & $5.90^{\mathrm{a}} \pm 0.21$ \\
\hline Monocytes $(103 / \mu \mathrm{l})$ & $0.40^{\mathrm{a}} \pm 0.08$ & $0.36^{\mathrm{a}} \pm 0.15$ & $0.42^{\mathrm{a}} \pm 0.03$ \\
\hline Neutrophils $(103 / \mu \mathrm{l})$ & $3.44^{\mathrm{a} \pm 0.43}$ & $3.40^{\mathrm{a} \pm 0.54}$ & $3.20^{\mathrm{a} \pm 0.15}$ \\
\hline Eosinophils $(103 / \mu \mathrm{l})$ & $0.09^{\mathrm{a}} \pm 0.05$ & $0.07^{\mathrm{a}} \pm 0.01$ & $0.08^{\mathrm{a}} \pm 0.01$ \\
\hline
\end{tabular}


(2009). Non significant changes were recorded in neutrophilic, monocytic and eosinophilic counts of infected groups. The same results were recorded by Krupakaran et al. (2009) and Ghanem and Abdel-Hamid (2010).

The present study revealed a significant increase in the serum activities of aminotransferases (AST and ALT) in the $2^{\text {nd }}$ and $3^{\text {rd }}$ groups. This could be due to degenerative changes induced by FMDV on the liver and heart. Also the significant increase in serum total, direct and indirect bilirubin levels may attribute to hepatocellular damage. On the same ground Nath et al. (2014) reported a significant increase in serum levels of AST, ALT, total; direct and indirect bilirubin in FMD infected cattle. On the contrary
El-Ashmawy et al. (2014) reported no significant change in serum ALT and AST activities in FMD infected cattle. This difference could be due to difference in the serotype (SAT2) and in the animal species.

The proteinogram of infected groups revealed a significant decrease in the serum levels of total proteins, albumin, globulins and albumin globulin ratio. The decreased $A / G$ ratio was due to the decrease in serum albumin was more than serum globulins. The hypoproteinemia could be attributed to hypoalbuminemia and hypoglobulinemia. The recorded hypoalbuminemia and hypo globulinemia may be due to decreased feed intake, decreased production by damaged liver, mal

Tab. 3. Effect of FMD on some biochemical parameters in buffaloes (mean values \pm SE)

\begin{tabular}{|c|c|c|c|}
\hline \multirow{2}{*}{ Parameters } & \multicolumn{3}{|c|}{ Groups } \\
\hline & Control & Early stage of FMD infection & Late stage of FMD infection \\
\hline Total proteins g/dl & $9.62^{\mathrm{a}} \pm 0.34$ & $6.50^{\mathrm{b}} \pm 0.18$ & $6.60^{\mathrm{b}} \pm 0.54$ \\
\hline Albumin g/dl & $4.96^{a} \pm 0.16$ & $3.10^{\mathrm{b}} \pm 0.16$ & $2.70^{\mathrm{b}} \pm 0.24$ \\
\hline Globulins g/dl & $4.62^{\mathrm{a}} \pm 0.31$ & $3.40^{\mathrm{b}} \pm 0.15$ & $3.90^{\mathrm{b}} \pm 0.12$ \\
\hline A/G Ratio & $1.06^{a} \pm 0.06$ & $0.92^{\mathrm{b}} \pm 0.06$ & $0.69^{c} \pm 0.04$ \\
\hline ALT U/L & $23.40^{c} \pm 1.10$ & $38.00^{\mathrm{a}} \pm 1.02$ & $34.00^{\mathrm{b}} \pm 0.41$ \\
\hline AST U/L & $33.80^{c} \pm 0.70$ & $58.20^{\mathrm{a}} \pm 1.20$ & $51.20^{\mathrm{b}} \pm 0.09$ \\
\hline Total bilirubin mg/dl & $0.30^{\mathrm{b}} \pm 0.01$ & $0.96^{a} \pm 0.08$ & $1.05^{\mathrm{a} \pm} \pm 0.09$ \\
\hline Direct bilirubin $\mathrm{mg} / \mathrm{dl}$ & $0.16^{\mathrm{b}} \pm 0.02$ & $0.20^{\mathrm{a}} \pm 0.03$ & $0.25^{\mathrm{a}} \pm 0.04$ \\
\hline Indirect bilirubin $\mathrm{mg} / \mathrm{dl}$ & $0.14^{\mathrm{b}} \pm 0.03$ & $0.76^{\mathrm{a}} \pm 0.12$ & $0.80^{\mathrm{a}} \pm 0.13$ \\
\hline Cholesterol mg/dl & $176.90^{\mathrm{a}} \pm 6.10$ & $104.00^{\mathrm{b}} \pm 4.00$ & $97.90^{\mathrm{b}} \pm 3.30$ \\
\hline Glucose mg/dl & $52.60^{c} \pm 2.50$ & $70^{\prime} .45^{b} \pm 3.40$ & $77.31^{\mathrm{a}} \pm 4.10$ \\
\hline Creatinine mg/dl & $1.40 \mathrm{a} \pm 0.80$ & $1.30^{\mathrm{a}} \pm 0.80$ & $1.30^{\mathrm{a}} \pm 0.40$ \\
\hline Progesterone ng/ml & $0.53^{\mathrm{a}} \pm 0.02$ & $0.13^{\mathrm{b}} \pm 0.01$ & $0.03^{c} \pm 0.0$ \\
\hline Ca mg/dl & $11.60^{\mathrm{a}} \pm 0.30$ & $8.80^{\mathrm{b}} \pm 0.49$ & $7.90^{\mathrm{b}} \pm 0.69$ \\
\hline $\mathrm{Ph} \mathrm{mg} / \mathrm{dl}$ & $6.30^{c} \pm 0.21$ & $7.10^{\mathrm{b}} \pm 0.18$ & $8.80^{\mathrm{a}} \pm 0.21$ \\
\hline Na mEq/L & $140.85^{\mathrm{a}} \pm 1.52$ & $120.35^{\mathrm{b}} \pm 1.42$ & $109.23^{c} \pm 1.76$ \\
\hline $\mathrm{K} \mathrm{mEq/L}$ & $4.49^{c} \pm 0.08$ & $5.35^{\mathrm{b}} \pm 0.10$ & $6.56^{a} \pm 0.18$ \\
\hline $\mathrm{NO} \mu \mathrm{mol} / \mathrm{ml}$ & $31.70^{\mathrm{b}} \pm 0.060$ & $40.20^{\mathrm{a}} \pm 1.00$ & $42.70^{\mathrm{a}} \pm 0.60$ \\
\hline $\mathrm{MDA} \mathrm{mmol} / \mathrm{ml}$ & $3.20^{\mathrm{b}} \pm 0.05$ & $6.80^{a} \pm 0.32$ & $6.70^{\mathrm{a} \pm} \pm 0.09$ \\
\hline cTnI $\mu \mathrm{g} / \mathrm{L}$ & $0.02^{c} \pm 0.01$ & $0.25^{b} \pm 0.01$ & $0.31^{\mathrm{a}} \pm 0.01$ \\
\hline LDH U/L & $230.00^{c} \pm 7.00$ & $420.00^{b} \pm 5.00$ & $450.00^{\mathrm{a}} \pm 4.00$ \\
\hline CK-MB U/L & $180.00^{c} \pm 4.20$ & $200.00^{\mathrm{b}} \pm 6.00$ & $274.00^{\mathrm{a}} \pm 3.80$ \\
\hline
\end{tabular}


digestion, mal absorption and exudation of plasma from ulcers (Nasr El- Deen, 2013).

Serum cholesterol level showed a significant decrease in the infected groups. Such decrease may be attributed to decreased intestinal absorption and decreased heptogenic lipogenic activity due to hepatic damage (Kaneko et al., 1997). Similar results were recorded by Gokce et al. (2004) and Ghanem and Abdel-Hamid (2010).

Serum creatinine level showed no significant change in FMD infected groups. This indicates that FMD has no negative impact on kidney function. Our results were in agreement with Gokce et al. (2004) and Ghanem and Abdel-Hamid (2010).

Serum glucose level showed a significant increase in the infected groups. The hyperglycemia may be due to insulin deficiency resulted from replication of FMDV in the pancreas causing destruction of the insulin producing cells (beta-cells). Also, hyperglycemia may be due to hypocalcaemia as calcium ions are required for insulin secretion. So, hypocalcaemia interfere with insulin secretion from pancreas (Kaneko et al., 1997). Similar result was obtained by Mousa and Galal 2013). On the other hand our results were disagreed with Krupakaran et al. (2009) who reported a significant reduction in blood glucose level in FMD infected cows. This difference could be due to the difference in animal species.

Compared with the normal control, the serum level of calcium was decreased significantly while a significant increase in serum phosphorus level was recorded in early and late stage of FMD infected buffaloes (gps. 2\&3). Hypocalcaemia may attribute to decreased feed intake, reduced calcium absorption from intestine and or hypoalbuminemia. Nearly similar results were reported by Nath et al. (2014) who recorded a significant decrease in serum calcium level in FMD infected cows. The hyperphosphatemia in the present work may be due to the decrease in serum calcium level and the increase of parathormone hormone as a result of hypocalcaemia (Breves and Schroder, 1999).

Foot and mouth disease infected buffaloes (gps. 2 \& 3) showed a significant hyponatremia and hyperkalemia compared with the normal control group. The recorded hyponatremia may be attributed to sodium loss through exudation from erosions, excessive salivation and/or decreased sodium intake due to starvation resulted from fever. The increase in serum potassium level may be due to the development of acidosis which resulted from bicarbonate losing during excessive salivation of infected animals (Kaneko et al., 1997). This leads to shifting of potassium to the extra cellular fluid and hydrogen ion to intra cellular fluid.

Concerning to the oxidative stress markers there was a significant increase in the serum level of MDA in the infected groups in comparison with the normal control group. This increase in the serum level of MDA may attribute to the viral infection which resulting in the release of reactive oxygen species (ROS) and reactive nitrogen species (RNS) (Zelnikova et al., 2008). These products are the main cause for inducing oxidative stress through cell damage as it can attack protein and nucleic acid of the cell. Moreover, it can also attack the polyunsaturated fatty acids of the membrane lipids causing lipid peroxidation (Halliwell et al., 1992). The main lipid peroxide by product is MDA (Heiderpour et al., 2013) which used as a good marker for oxidative damage (Kandemir et al., 2011). The body minimizes the effect of ROS by the production of antioxidants which depleted with the increase of ROS.

The present study showed a significant increase in the NO level in the 2nd and 3rd groups compared with the normal control group. This increase may attributed to that the infectious diseases activate macrophage to produce large quantities of nitric oxide that play an important role in the defense mechanism and has cytotoxic effect on these agents (Rockett et al., 2007). This result agreed with the previously studies by Gokce et al., (2004), Zaher and Ahmed (2008).

The present work showed that FMD infection caused inactivation for ovaries as clarified by both clinic and gynecological examination. This ovarian inactivity was represented by a significant decrease in serum progesterone level and presence of smooth ovaries. Our results supported the previously obtained by Zaher and Ahmed (2008) and Nath et al. (2015). This ovarian inactivity in the infected female buffaloes could be attributed to the poor body condition following fever and depressed appetite that inhibits ovarian function (Ahmed et al., 2006). Moreover, the oxidative stress play an important role in the female reproductive biology mainly influence function by affecting 
growth of ovarian follicles and oocyt maturation (Megahed et al., 2002).

\section{CONCLUSION}

It could be concluded that foot and mouth disease virus (serotype 0 ) caused megaloblastic anemia with alterations in total and differential leukocytic counts. Alterations in the hepatic function. Negative impact on the reproductive performance of the female animals. Increasing the oxidative stress with negative impact on the heart.

\section{REFERENCES}

1. Ahmed WM, El-Khadrawy $\mathrm{HH}$ and Abd El-Hamed AR (2006). Applied investigations on ovarian inactivity in buffaloes. Preceding the Third International Conference of Veterinary Research Division. Vet. Res. Center, Egypt, pp:1-15.

2. Aidaros HA (2002). Regional status and approaches to control and eradication of foot and mouth disease in the Middle East and North Africa. Rev. Sci. Tech., 21(3):451458.

3. Ali SM, Yousef MR, Sharawi SSA and Al-Blowi MH (2011). Detection of Foot-and-Mouth Disease Sub-clinical infection in sheep imported from free zones of Georgia during Hajj season 2009 in Kingdom of Saudi Arabia. Veterinary World, 4(9): 399-403.

4. Armstrong RM, Barnett IT (1989). An enzyme-linked immunosorbent assay (ELISA) for the detection and quantification of antibodies against swine vesicular disease virus (SVDV). J Virol Methods, 25(1): 71-79.

5. Baluka SA (2016). Economic effects of foot and mouth disease outbreaks along the cattle marketing chain in Uganda. Vet World, 9(6):544-553.

6. Berrios EP (2007). [Foot and mouth disease in human beings. A human case in Chile]. Rev Chilena Infectol, 24(2):160-163.

7. Blancou J (2002). History of the control of foot and mouth disease. Comp Immunol Microbiol Infect Dis, 25(56):283-296.

8. Breves G, Schroder B (1999).Calcium metabolism in ruminant physiological aspects and effect of anion rich diets. Proc. Soc. Nutr. Physiol., 8:27-35.

9. Buffaloes and Calves naturally infected with Foot and Mouth Disease Virus serotype

10. Clavijo A, Wright P, Kitching P (2004). Developments in diagnostic techniques for differentiating infection from vaccination in foot-and-mouth disease. Vet J, 167(1):9-22.

11. DeClercq K (2002). Overview on FMD diagnostic techniques. In FMD control strategies, Symposium Proceedings, 2-5 June 2002, Lyon, France, pp. 345-351.

12. Diaz S and Sevilla S (2006). Selective lymphocyte depletion during early stage of immune response to foot and mouth disease virus infection in swine. Journal of Virology, 80: 2369-2379.
13. Douglas K, Wardrop KJ (2010). Schalm's Veterinary Hematology (6th edition ed.). Philadelphia and Baltimore: Black Well.

14. El-Shehawy LE, El-Kilaany S, Doaud AM (2004). 3 ABC ELISA for diagnosis of FMD in Egyptian sheep. Report of the Session of the Research Group of European Commission for the Control of Foot and Mouth Disease. Turkey, Rome, FAO, 416-422.

15. Ghanem MM, Abdel-Hamid 0 (2010). Clinical, haematological and biochemical alterations in heat intolerance (panting) 12 syndrome in Egyptian cattle following natural foot-and-mouth disease (FMD). Trop. Anim. Health Prod., 42(6):1167-1173.

16. Gokce C, Guns V, Erdogan M and Citil M (2004). Alterations in Some Haematological and Biochemical Parameters in Cattle Suffering from Foot-and-Mouth Disease. Turk. J. Vet. Anim. Sci., 28:723-727.

17. Grazioli S, Fallacara F, Brocchi E (2013). Mapping of antigenic sites of foot-and-mouth disease virus serotype Asia 1 and relationships with sites described in other serotypes. J Gen Virol, 94(3):559-569.

18. Halliwell B, Gutteridge JM, Cross CE (1992). Free radicals, antioxidants, and human disease: where are we now? J. Lab. Clin. Med., 119(6):598-620.

19. Hamblin C, Kitching RP, Donaldson AI, Crowther JR, Barnett IT (1987). Enzyme-linked immunosorbent assay (ELISA) for the detection of antibodies against foot-andmouth disease virus. III. Evaluation of antibodies after infection and vaccination. Epidemiology and Infection, 99(3):733-744.

20. Heiderpour M, Mohri M, Borji H and Moghdass E (2013). Oxidant/antioxidant status in cattle with liver cystic echinococcosis. Vet. Parasitol., 195(1-2):131-135.

21. Kandemir FM, Issi M, Benzer F, Gul Y, Basbug 0 and Ozdemir N (2011). Plasma nitric oxide concentrations and erythrocyte arginase activities in lambs with contagious ecthyma. Revue Med. Vet., 162(6):275-278.

22. Kaneko JJ, Harvey JW and Bruss ML(1997). Clinical Biochemistry of Domestic Animals. 5th Ed. Academic Press San Diego, California, USA. app 661-668.

23. Krupakaran RP, Porcheziyan T and Sivseelan S (2009). Biochemical and haematological profile of foot and mouth disease affected crossbred cows in Karur district of Tamil Nadu. Veterinary Practitioner, 10(1):37-38.

24. Longjam N, Deb R, Sarmah AK, Tayo T, Awachat VB, Saxena VK (2011). A Brief Review on Diagnosis of Foot-andMouth Disease of Livestock: Conventional to Molecular Tools. Veterinary Medicine International, 2011, 905768. doi:10.4061/2011/905768

25. Lubroth J (2002). Foot-and-mouth disease. A review for the practitioner. Vet Clin North Am Food Anim Pract, 18(3):475-499.

26. Mahmoud EA, Neamat-Allah ANF (2016). HematoBiochemical studies on Egyptian buffaloes and calves naturally infected with foot and mouth disease serotype SAT 2. The Bulletin of University of Agricultural Sciences and Veterinary Medicin Cluj-Napoca. Veterinary Medicine, 73(2):230-237. 
27. Megahed GA, Anwar MM and El-Ballal SS (2002). Superoxide dismutase, nitric oxide and lipid peroxide production and its relation to apoptotic changes and serum progesterone life span and buffalo corpora lutea. Minufyia Vet. Medicine J, 2: 99-112.

28. Mousa SA and Galal MK (2013). Alteration in clinical and hemobiochemical and oxidative stress parameters in Egyptian cattle infected with foot and mouth disease. J. Anim. Sci. Adv., 3(9):485-491.

29. Nasr El-Deen NA (2013). Clinicopathological studies on the effect of foot and mouth disease in Egyptian buffaloes. Zag. Vet. J., 41(5):133-141.

30. Nath R, Prasad R and Sarma S (2014). Oxidative stress biomarkers in cross bred cows affected with foot and mouth disease. Indian J. Anim. Res., 48(6):628-632.

31. Nath R, Prasad RL, Deka SS, Adil A, Senapatti M and Islam M. (2015). Impact of Foot and Mouth disease on ovarian activity in cows. Sch. J. Agric. Vet. Sci., 2(3A):166-168.

32. Olabode HO, Kazeem HM, Raji MA, Ibrahim ND, Adeh BM and Obafemi FM (2013). Hematological variations associated with bovine foot and mouth disease virus infection. J. Vet. Ad., 3(9):245-250.

33. Parida S, Reid SM, Cox SJ, Statham RJ, Mahapatra M, Anderson J, Barnett PV, Charleston B and Paton DJ (2006) Interferon-gamma production in vitro from whole blood of foot-and-mouth disease virus (FMDV) vaccinated and infected cattle after incubation with inactivated FMDV. Vaccine, 24(7):964-969.

34. Radostits O, Gray C, Hinchcliff K, Constable P (2007). Veterinary Medicine:A Text Book of the Disease of Cattle, Horses, Sheep, Pigs and Goats. London: Saunders Elsevier.

35. Reid SM, Grierson SS, Ferris NP, Hutchings GH, Alexandersen S (2003). Evaluation of automated RT-PCR to accelerate the laboratory diagnosis of foot-and-mouth disease virus. Journal of Virological Methods, 107(2):129139.

36. Rockett KA, Awburn MM, Rockett EJ, Cowden WB and Clark IA (2007). Possible role of nitricoxide in malarial immune suppression. Parasit. Immunal., 16(5):243-249.

37. Rodriguez LL, Gay CG (2011). Development of vaccines toward the global control and eradication of foot-andmouth disease. Expert Review of Vaccines, 10(3):377-387.

38. Sellers R, Gloster J (2008). Foot-and-mouth disease: a review of intranasal infection of cattle, sheep and pigs. Vet J, 177(2):159-168.

39. Sorensen KJ, Madsen KG, Madsen ES, Salt JS, Nqindi J, Mackay DK (1998). Differentiation of infection from vaccination in foot-and-mouth disease by the detection of antibodies to the non-structural proteins $3 \mathrm{D}, 3 \mathrm{AB}$ and $3 \mathrm{ABC}$ in ELISA using antigens expressed in baculovirus. Arch Virol, 143(8):1461-1476.

40. Tamhane A, Dunlop D (2000). Statistic and data analysis from elementary to intermediate. New Jersey.USA: Prentice Hall, Upper Saddle River.

41. Valdazo-González B, Knowles NJ, Hammond J, King DP (2012). Genome Sequences of SAT 2 Foot-and-Mouth Disease Viruses from Egypt and Palestinian Autonomous Territories (Gaza Strip). Journal of Virology, 86(16):89018902.

42. Zaher KS and Ahmed WM (2008). Impact of foot and mouth disease on oxidative status and ovarian activity in Egyptian buffaloes. World Journal of Zoology, 3(1):01-07.

43. Zelnikova P, Matiasovic J, Pavlova B, Kudlackova H, Kovaru F and Faldyna M (2008). Quantitative nitric oxide production by rat, bovine and poreine macrophages. Nitric Oxide, 19(1):36-41. 